\title{
EKOLOGI DAN STRUKTUR KOMUNITAS LAMUN DI TELUK RATATOTOK, MINAHASA TENGGARA, SULAWESI UTARA
}

\author{
Mariska A. Kusumaningtyas ${ }^{1}$, Agustin Rustam ${ }^{1)}$, Terry L. Kepel'1), Restu Nur Afi Ati ${ }^{1}$, August Daulat ${ }^{11}$, \\ Peter Mangindaan ${ }^{1)}$ \& Andreas A. Hutahaean"1)
}

1)Pusat Penelitian dan Pengembangan Sumber Daya Laut dan Pesisir, Balitbang-KP, KKP

Diterima tanggal: 30 Oktober 2015; Diterima setelah perbaikan: 17 Desember 2015; Disetujui terbit tanggal 25 Januari 2016

\begin{abstract}
ABSTRAK
Penelitian mengenai ekologi dan struktur komunitas lamun ini dilakukan tanggal 10 - 15 Juni 2013 di perairan pesisir Teluk Ratatotok, Minahasa Tenggara. Metode penelitian dilakukan secara purposive sampling terkait dengan keberadaan lamun. Penelitian yang dilakukan meliputi pengukuran prosentase tutupan lamun, kerapatan, struktur komunitas, dan kondisi lingkungan di lokasi penelitian. Terdapat tujuh jenis lamun yang terdiri dari dua famili. Famili Hydrocharitaceae mencakup tiga jenis yaitu Enhalus acoroides (Ea), Thalassia hemprichii (Th) dan Halophila ovalis (Ho). Empat jenis lamun dari famili Cymodoceaceae yaitu Cymodocea serrulata (Cs), Cymodocea rotundata (Cr), Halodule pinifolia (Hp), dan Syringodium isoetifolium ( $\mathrm{Si}$ ). Kisaran prosentase penutupan rata-rata antara $22,5 \%-89,5 \%$. Kerapatan lamun per stasiun berkisar antara $17-473 \mathrm{ind} / \mathrm{m}^{2}$, dengan kerapatan tertinggi lamun jenis Ho sebesar $473 \mathrm{ind} / \mathrm{m}^{2}$ di stasiun 6 . Nilai INP tertinggi pada lamun jenis Ea sebesar $128 \%$ diikuti berturut-turut oleh Si $(41 \%)$, Th (36\%), Ho (27\%), Cs $(26 \%)$, Cr $(24 \%)$ dan Hp (17\%). Berdasarkan kriteria status kondisi padang lamun (Kepmen LH No 200 tahun 2004), kondisi padang lamun di Teluk Ratatotok antara rusak/ miskin sampai dengan baik/sehat. Stasiun 5 kondisi rusak/miskin, stasiun 3 dan 4 kondisi rusak/kurang sehat dan tiga stasiun kondisi baik/sehat yaitu stasiun 1, 2 dan 6. Secara keseluruhan kondisi lingkungaan Teluk Ratatotok masih mendukung pertumbuhan lamun.
\end{abstract}

\section{Kata kunci: lamun, ekologi, struktur komunitas, Teluk Ratatotok}

\section{ABSTRACT}

The study of seagrass ecology and community structure was conducted on 10 - 15 June 2013 in the coastal waters of Ratatotok Bay, Southeast Minahasa. The research method was using purposive sampling. The research consisted of the measurement of the percentage of seagrass cover, density, community structure and environmental conditions at the sites. There were seven species of seagrass found during this study grouped into two families. Family Hydrocharitaceae with three species were Enhalus acoroides (Ea), Thalassia hemprichii (Th) and Halophila ovalis (Ho). Four species of family Cymodoceaceae were Cymodocea serrulata (Cs), Cymodocea rotundata (Cr), Halodule pinifolia ( $\mathrm{Hp}$ ) and Syringodium isoetifolium (Si). The average percentage range is between $22.5 \%-89.5 \%$. Seagrass density in each station ranged between $17-473 \mathrm{ind} / \mathrm{m}^{2}$, with the highest density of Ho species as $473 \mathrm{ind} / \mathrm{m}^{2}$ at station 6 . The highest Importance Value Index in seagrass species was Ea $(1.28 \%)$ followed by Si (41\%), Th (36\%), Ho (27\%), Cs (26\%), Cr (24\%) and Hp (17\%) respectively. Based on the criteria for the status of seagrass condition (Decree Minister of EnvironmentNo. 200 of 2004) the condition of seagrass beds in the Ratatotok Bay between damaged/poor to good/healthy condition. Condition in station 5 was damaged/poor, station 3 and 4 were damaged/unhealthy and three stations were in good condition thosewere station 1, 2 and 6. In overall, the environment condition of Ratatotok Bay still can support the seagrass growth.

Keywords: seagrass, ecology, community structure, Ratatotok Bay

\section{PENDAHULUAN}

Lamun termasuk ke dalam tumbuhan angiosperma akuatik yang dapat tumbuh di perairan laut (Hartog \& Kuo, 2006). Tumbuhan lamun memiliki organ dan jaringan yang sama dengan tumbuhan berbunga lainnya, terdiri atas akar, rhizoma/batang di bagian bawah serta tunas dan daun di bagian atas (Kuo \& den Hartog, 2006). Eksistensi lamun di laut merupakan hasil dari beberapa adaptasi fisiologi dan morfologi pada kondisi terbenam, termasuk toleransi terhadap salinitas yang tinggi, transport gas internal, kemampuan untuk menancapkan akar di substrat sebagai jangkar, dan juga kemampuan untuk tumbuh dan melakukan reproduksi pada saat terbenam. Sehingga padang lamun membentuk ekologi yang unik, dimana keberadaan padang lamun dengan fungsinya mampu menciptakan lingkungan yang memenuhi kebutuhannya sendiri seperti kebutuhan Korespondensi Penulis:

Jl. Pasir Putih I Ancol Timur, Jakarta Utara 14430. Email: m.astridkusuma@yahoo.com nutrien, pola reproduksi dari biji yang dapat bersifat dorman untuk species Zostera spp dan Halophila spp atau tidak seperti Enhalus acoroides (Marba et al., 2006; Orth et al., 2006).

Padang lamun memiliki peran dan fungsi ekologi yang penting di ekosistem pesisir. Ekosistem lamun mempunyai fungsi selain sebagai produsen juga sebagai habitat biota (tempat pemijahan, daerah asuhan, daerah mencari makan), sebagai penangkap sedimen, serta sebagai pendaur zat hara. Menurut Phillips \& Menez (1988), ekosistem lamun merupakan salah satu ekosistem bahari yang produktif di perairan dangkal, mempunyai fungsi antara lain: 1) Menstabilkan dan menahan sedimen-sedimen yang dibawa melalui tekanan-tekanan dari arus dan gelombang (sediment trap); 2) Daun-daun memperlambat dan mengurangi arus dan gelombang serta meningkatkan sedimentasi; 3) Memberikan perlindungan terhadap hewan-hewan 
muda dan dewasa yang berkunjung ke padang lamun; 4) Daun-daun sangat membantu organismeorganisme epifit; 5) Mempunyai produktifitas dan pertumbuhan yang tinggi; 6) Menfiksasi karbon di kolom air sebagian masuk ke dalam sistem daur rantai makanan dan sebagian tersimpan dalam biomassa dan sedimen.

Tumbuhan lamun tersebar di perairan pesisir seluruh benua kecuali antartika, namun demikian keanekaragaman taksonominya rendah. Berdasarkan Kuo \& McComb (1989) jumlah tumbuhan lamun mencapai 58 jenis di seluruh dunia, sementara studi lain menyatakan terdapat 60 jenis lamun yang dikelompokkan kedalam 15 generasi dari 5 famili dengan konsentrasi utama ditemukan di wilayah IndoPasifik. Jumlah tersebut jauh lebih sedikit dibandingkan organisme laut lainnya (Short et al., 2001; Green \& Short, 2003; Hemminga \& Duarte, 2004). Dari jumlah jenis tersebut, 16 spesies dari 7 genus diantaranya ditemukan di perairan Asia Tenggara, dimana jumlah spesies terbesar ditemukan di perairan Filipina sebanyak 16 spesies atau dapat dikatakan semua spesies yang ada di perairan Asia Tenggara ditemukan juga di Filipina. Di Indonesia ditemukan jumlah jenis lamun yang relatif lebih rendah dibandingkan Filipina, yaitu sebanyak 12 spesies dari 7 genus.
Perairan pesisir merupakan lingkungan yang memperoleh sinar matahari cukup yang dapat menembus sampai ke dasar perairan. Perairan ini juga kaya akan nutrien karena mendapat pasokan dari dua tempat yaitu darat dan lautan sehingga merupakan ekosistem yang tinggi produktivitas organiknya. Lingkungan yang sangat mendukung di perairan pesisir menyebabkan tumbuhan lamun dapat hidup dan berkembang secara optimal.

Teluk Ratatotok merupakan daerah yang berada di Minahasa Tenggara bagian dari Teluk Tomini. Keberadaan lamun di Teluk Ratatotok belum banyak diketahui, umumnya penelitian yang dilakukan di Teluk Ratatotok terfokus atas keberadaan terumbu karang. Penelitian ini bertujuan untuk mendapatkan informasi kondisi ekologi dan struktur komunitas lamun dan kondisi lingkungan di lokasi penelitian. Penelitian mengenai ekosistem lamun di Teluk Ratatotok ini merupakan yang pertama kali dilakukan di lokasi tersebut.

\section{METODE PENELITIAN}

Lokasi penelitian berada di Kabupaten Minahasa Tenggara. Secara Geografis, Kabupaten Minahasa Tenggara terletak antara $124^{\circ} 30^{\prime} 24^{\prime \prime}$ - $124^{\circ} 56^{\prime} 24^{\prime \prime}$ BT dan 1008'19" - $0^{\circ} 50^{\prime} 46$ " LU. Lokasi penelitian lamun

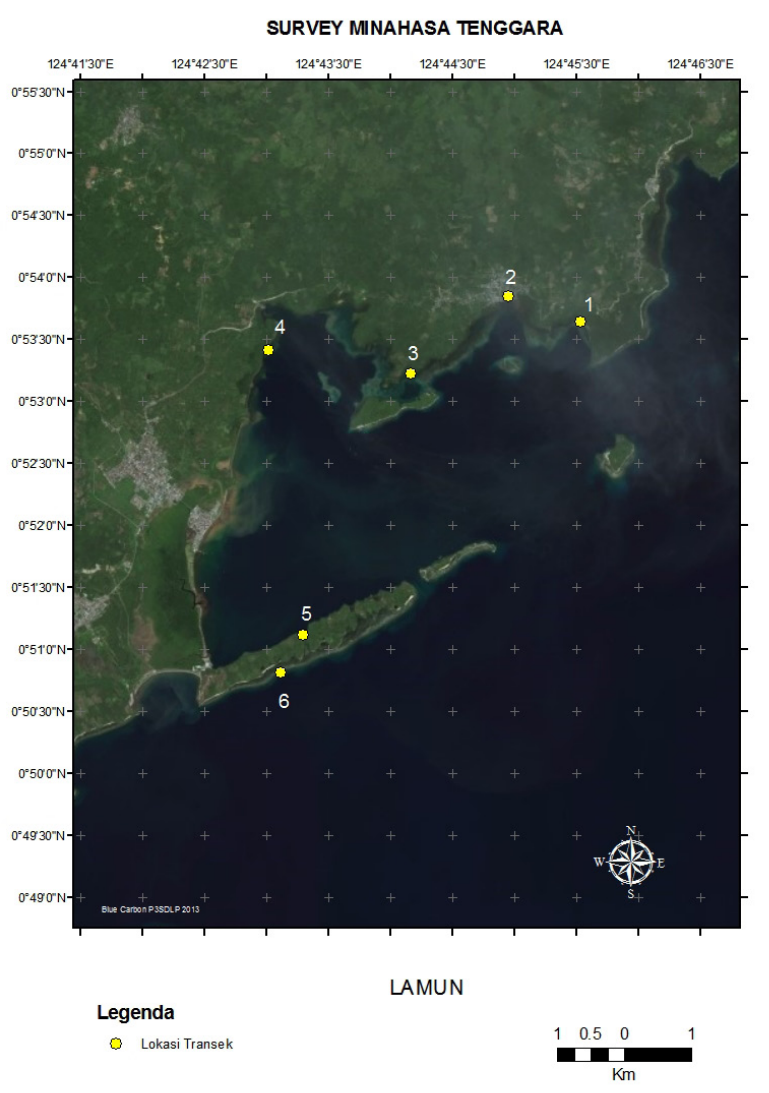

Gambar 1. L Lokasi penelitian di Teluk Ratatotok, Minahasa Tenggara, Juni 2013. 
terfokus pada kecamatan Ratatotok yang memililiki luas 10,418 Ha tepatnya di Teluk Ratatotok. Terdapat enam lokasi keberadaan lamun di Teluk Ratatotok, Minahasa Tenggara, yaitu stasiun 1 sampai dengan stasiun 6. Lokasi penelitian dapat dilihat pada Gambar 1.

Teluk Ratatotok merupakan bagian dari teluk besar yaitu Teluk Tomini. Perairan ini berada di daerah Kabupaten Minahasa Tenggara, Kecamatan Ratatotok, Provinsi Sulawesi Utara. Kondisi perairan secara visual masih dalam kondisi bagus dengan aktivitas yang terdapat di Teluk Ratatotok adanya budi daya kerang mutiara, budi daya keramba jaring apung dan perikanan tangkap tradisional oleh para nelayan. Teluk Ratatotok dalam Rencana Tata Ruang dan Wilayah (RTRW) Kabupaten Minahasa Tenggara merupakan daerah wisata, aktivitas perikanan budidaya perikanan tangkap, kawasan strategis kepentingan ekonomi, kawasan strategis fungsi dan daya dukung lingkungan serta ditetapkan sebagai salah satu kawasan minapolitan (Anonim, 2013).

Metode penelitian dilakukan secara purposive sampling yang diharapkan dapat mewakili lokasi penelitian berdasarkan keberadaan lamun dengan menggunakan perahu dan berjalan kaki. Metode pengambilan data lamun dilakukan secara line transect yang mengadopsi SeagrassWatch. Transek garis ditarik tegak lurus garis pantai sepanjang $50 \mathrm{~m}$, kemudian kuadrat berukuran $50 \times 50 \mathrm{~cm}^{2}$ diletakkan secara sistematik di sepanjang transek dengan jarak antar kuadrat $10 \mathrm{~m}$.

Parameter yang diambil di setiap stasiun penelitian adalah persentase tutupan tajuk lamun dalam setiap kuadrat $50 \times 50 \mathrm{~cm}^{2}$, dilakukan dengan metode estimasi visual berdasarkan panduan persentase tutupan lamun standar SeagrassWatch (McKenzie et al., 2003). Persentase tutupan yang diambil adalah persentase tutupan total lamun dan persentase tutupan setiap jenis lamun dalam kuadrat. Dilakukan penghitungan jumlah tunas lamun untuk lamun berukuran besar (E.acoroides) dihitung di setiap kuadrat $50 \times 50 \mathrm{~cm}^{2}$, sedangkan untuk spesies lainnya dilakukan pengambilan spesimen dalam core berukuran 0,0591608 $\mathrm{m}^{2}$. Spesimen dimasukkan kedalam plastik berlabel dan penghitungan jumlah individu dalam kuadrat tersebut dilakukan di base camp. Setiap jenis lamun yang ditemukan juga diambil sebagai spesimen untuk diidentifikasi ulang.

Analisa struktur komunitas lamun dilakukan untuk mengetahui kondisi ekosistem lamun. Analisa yang dilakukan adalah menghitung komposisi jenis lamun, menghitung frekuensi jenis dan frekuensi relatif, menghitung kerapatan jenis dan kerapatan relatif, menghitung penutupan jenis dan penutupan relatif, dan untuk menduga keseluruhan dari peranan suatu jenis lamun dilakukan perhitungan Indeks Nilai Penting (INP).

\section{a. Komposisi Jenis}

Untuk mengetahui komposisi jenis dilakukan dengan membandingkan antara jumlah individu masing-masing jenis dengan jumlah total individu jenis lamun yang ditemukan.

\section{b. Frekuensi dan Frekuensi Relatif}

- Frekuensi Jenis (Fi) lamun menggambarkan peluang suatu jenis ditemukan dalam titik sampel yang diamati. Perhitungan Frekuensi jenis lamun mengacu pada Fachrul (2007), sebagai berikut:

$$
F i=\frac{P i}{\sum P i}
$$

$$
\begin{aligned}
& \text { Keterangan: } \\
& \mathrm{Fi}=\text { Frekuensi jenis ke- } \mathrm{i} \\
& \mathrm{Pi}=\text { Jumlah petak sampel tempat ditemukan } \\
& \quad \text { jenis ke-i } \\
& \Sigma \mathrm{Pi}=\text { Jumlah total petak sampel yang diamati }
\end{aligned}
$$

- Frekuensi relatif (FR), yaitu perbandingan antara Frekuensi jenis ke-i (Fi) dan jumlah Frekuensi untuk seluruh jenis (Fachrul 2007), sebagai berikut:

$$
F R=\frac{F i}{\sum F i}
$$

Keterangan:

$\mathrm{FR}=$ Frekuensi Relatif

$\mathrm{Fi}=$ Frekuensi jenis ke- $\mathrm{i}$

$\Sigma \mathrm{Fi}=$ Jumlah Frekuensi untuk seluruh jenis

\section{c. Kerapatan}

- Kerapatan Jenis (Ki), yaitu jumlah total individu jenis dalam suatu unit area yang diukur. Kerapatan jenis lamun dihitung dengan mengacu pada Fachrul (2007), sebagai berikut:

$$
K i=\frac{N i}{A}
$$

Keterangan:

$\mathrm{Ki}=$ Kerapatan jenis ke- $\mathrm{i}$

$\mathrm{Ni}=$ Jumlah total individu dari jenis ke-i

$A=$ Luas area total pengambilan sampel $\left(\mathrm{m}^{2}\right)$ 
- Kerapatan Relatif (KR), yaitu perbandingan antara jumlah individu jenis dan jumlah total individu semua jenis (Fachrul 2007), sebagai berikut:

$$
K R=\frac{n i}{\sum n i}
$$

Keterangan:

$\mathrm{KR}=$ Kerapatan Relatif ke-i

$\mathrm{ni}=$ Jumlah individu spesies ke-i

$\sum \mathrm{ni}=$ Jumlah total individu semua jenis

\section{d. Penutupan}

- Penutupan Jenis (Pi), yaitu luas area yang ditutupi oleh jenis lamun. Penutupan jenis lamun dapat dihitung menggunakan metode Saito and Atobe (English et al. 1994), dengan rumus:

$$
C=\frac{\sum(M i x f i)}{\sum f}
$$

Keterangan:

$\mathrm{C}=$ Penutupan jenis lamun ke-i (\%)

$\mathrm{Mi}=$ Nilai tengah kelas ke-i

$\mathrm{f}=$ Frekuensi (jumlah sub kuadrat yang memiliki nilai tengah yang sama)

- Penutupan Relatif (PR), yaitu perbandingan antara penutupan individu jenis ke-i dan total penutupan seluruh jenis. Penutupan relatif lamun dapat dihitung dengan rumus:

$$
P R=\frac{\text { penutupanjeniskei }}{\text { penutupanseluruhjenis }}
$$

\section{e. Indeks Nilai Penting}

Indeks Nilai Penting (INP) (Brower et al., 1990) digunakan untuk menghitung dan menduga keseluruhan dari peranan jenis lamun didalam suatu komunitas (Brower et al., 1990). Semakin tinggi nilai
INP suatu jenis relatif terhadap jenis lainnya, semakin tinggi peranan jenis pada komunitas tersebut. Rumus yang digunakan untuk menghitung INP adalah:

$$
I N P=F R+K R+P R
$$

$$
\begin{aligned}
& \text { Keterangan: } \\
& \text { INP = Indeks Nilai Penting } \\
& \text { FR = Frekuensi Relatif } \\
& \text { KR = Kerapatan Relatif } \\
& \text { PR }=\text { Penutupan Relatif }
\end{aligned}
$$

\section{HASIL DAN PEMBAHASAN}

Hasil pengukuran kondisi lingkungan perairan di Teluk Ratatotok dapat dilihat dalam Tabel 1. Parameter yang diukur dengan alat ukur multiparameter merk TOA ada tujuh parameter.

Nilai turbiditas/kekeruhan tinggi yaitu 52,83 NTU di stasiun 2 yang merupakan stasiun yang berada di dekat muara sungai dan pemukiman penduduk dan terdapat padang lamun monospesies Ea dengan substrat lumpur. Nilai $\mathrm{pH}$, temperatur dan salinitas merupakan nilai alami yang terukur. Klorofil hanya terukur secara insitu di stasiun 2, stasiun lainnya nilai klorofil tidak terukur.

Hasil penelitian lamun di Teluk Ratatotok didapatkan tujuh spesies lamun yang terdiri dari dua famili yaitu Hydrocharitaceae dan Cymodoceaceae. Tiga jenis dari famili Hydrocharitaceae yaitu Enhalus acoroides, Thalassia hemprichii, dan Halophila ovalis. Empat jenis dari famili Cymodoceaceae yaitu Cymodocea serrulata, Cymodocea rotundata, Halodule pinifolia dan Syringodium isoetifolium. Jenis lamun yang ditemukan di enam lokasi pengamatan dapat dilihat dalam Tabel 2. Diketahui di perairan Indonesia terdapat 12 jenis lamun yang dapat ditemukan, walaupun menurut Kiswara (2009) Indonesia memiliki 14 jenis lamun dimana dua jenis lamun berupa herbarium di Museum Botani, Bogor yaitu Ruppia maritime, dan Halophila beccarii.

Tabel 1.

Parameter lingkungan yang terukur di ekosistem lamun Teluk Ratatotok, Minahasa Tenggara, Sulawesi Utara bulan Juni 2013

\begin{tabular}{llllll}
\hline Parameter & \multicolumn{2}{l}{ Minimum } & \multicolumn{2}{l}{ Maksimum } & Rata-rata \\
\hline pH & 8,01 & 8,29 & 8,15 & \pm & 0,21 \\
Cond (mS/m) & 4,30 & 4,48 & 4,39 & \pm & 0,13 \\
Turbidity (NTU) & 2,47 & 52,83 & 27,65 & \pm & 35,62 \\
Temperatur ( C) & 30,27 & 31,83 & 31,05 & \pm & 1,11 \\
Salinitas (PSU) & 28,47 & 30,00 & 29,23 & \pm & 1,08 \\
Sigma t & 16,70 & 17,30 & 17,00 & \pm & 0,42 \\
Chlorofil-a ( $\mu \mathrm{g} / \mathrm{L})$ & 0,00 & 0,03 & 0,02 & \pm & 0,02 \\
\hline
\end{tabular}


Tabel 2 menunjukkan bahwa jenis lamun lebih banyak ditemukan di stasiun 1 sebanyak enam jenis dan paling sedikit ditemukan di stasiun 2 dan stasiun 5 yang merupakan padang lamun monospesies. Stasiun 2 terletak dekat dengan muara sungai dengan substrat berlumpur, padang lamun Ea pada saat surut terendah memiliki kedalaman kurang lebih $1 \mathrm{~m}$. Lamun jenis Ea yang terdapat pada stasiun ini terlihat besar-besar dengan panjang helaian daun mencapai lebih dari 1 m. Stasiun 5 yang terletak di Tanjung Buyat sisi dalam Teluk Ratatotok merupakan daerah terumbu karang dengan lamun yang ditemukan hanya jenis Ea yang tumbuh diantara karang dan makro alga. Makro alga banyak di stasiun ini seperti Padina sp, Sargassum sp, Halimeda sp dan Caulerpa sp.

Stasiun 1, 3, 4 dan 6 merupakan stasiun yang dekat dengan daratan utama, dimana substrat umumnya terdiri dari pasir dan pecahan karang. Keanekaragaman lamun yang ditemukan pada keempat stasiun ini lebih dari satu jenis. Stasiun 3 lamun yang ditemukan berupa spot-spot kecil di depan ekosistem mangrove. Stasiun 1 lamun ditemukan di depan stasiun mangrove terbentuk padang lamun monospesies lamun jenis Cymodocea serrulata (Cs) sejauh kurang lebih $50 \mathrm{~m}$. Selanjutnya terbentuk padang lamun campuran, dimana pada stasiun ini banyak ditemukan teripang diantara lamun. Stasiun 6 terbentuk padang lamun campuran yang cukup padat, umumnya terdiri dari tiga jenis lamun yaitu $\mathrm{Cs}$, Ea dan Si.

Komposisi lamun yang ditemukan di Teluk Ratatotok lebih dari $50 \%$ adalah jenis Ea (54\%), urutan kedua sampai keempat adalah Si $14 \%$, Th $12 \%$ dan Cs 10\%. Komposisi lamun yang ditemukan untuk lebih jelasnya dapat dilihat pada Gambar 2.

Gambar 2 menunjukkan komposisi jenis lamun di Teluk Ratatotok di dominasi oleh jenis Ea sebesar 54\%.

Tabel 2.

Keberadaan spesies lamun di perairanTeluk Ratatotok, Minahasa Tenggara, Sulawesi Utara, Juni 2013

\begin{tabular}{lllllll}
\hline Jenis Lamun & \multicolumn{7}{c}{ Stasiun } \\
\cline { 2 - 7 } & 1 & 2 & 3 & 4 & 5 & 6 \\
\hline Hydrocharitaceae & & & & & & \\
Enhalusacoroides & $\mathrm{X}$ & $\mathrm{X}$ & $\mathrm{X}$ & $\mathrm{X}$ & $\mathrm{X}$ & $\mathrm{X}$ \\
Halophilaovalis & $\mathrm{X}$ & & & $\mathrm{X}$ & & \\
Thalassiahemprichii & $\mathrm{X}$ & & & $\mathrm{X}$ & & \\
Cymodoceaceae & & & & & & $\mathrm{X}$ \\
Cymodoceaserrulata & & & $\mathrm{X}$ & $\mathrm{X}$ & & $\mathrm{X}$ \\
Cymodocearotundata & $\mathrm{X}$ & & & & & $\mathrm{X}$ \\
Syringodiumisoetifolium & $\mathrm{X}$ & & & & & \\
Halodulepinifolia & $\mathrm{X}$ & & & $\mathrm{X}$ & & \\
Keterangan: X= ada & & & & & & \\
\hline
\end{tabular}

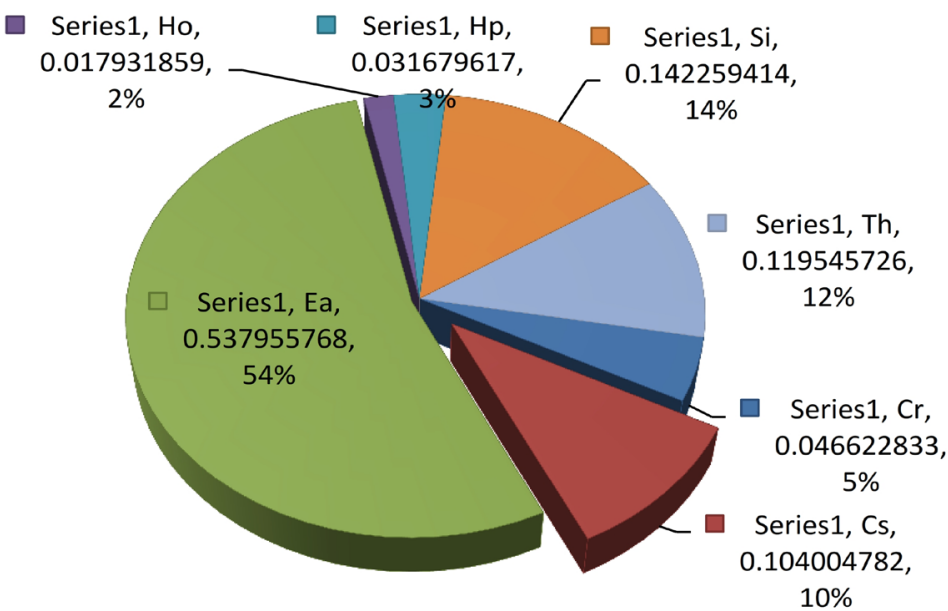

Gambar 2. Komposisi lamun yang ditemukan di Teluk Ratatotok, Minahasa Tenggara, Sulawesi Utara, pada bulan Juni 2013. 
Urutan kedua dan ketiga adalah Si sebesar 14\% dan Th sebesar $12 \%$. Berdasarkan pengamatan di perairan Teluk Ratatotok jenis Ea yang tumbuh berukuran cukup besar dan ditemukan di seluruh stasiun pengamatan.

Prosentase tutupan total lamun di perairan Teluk Ratatotok berkisar antara 10\% - 100\%. Stasiun 2 berdasarkan pengamatan secara visual terlihat padang lamun monospesies Ea dengan prosentase tutupan berkisar $80 \%$. Stasiun ini merupakan stasiun dekat dengan muara sungai dan pemukiman. Padang lamun monospesies terlihat cukup luas berkisar antara 4 - 10 ha. Ea berukuran besar dengan panjang daun mencapai lebih dari $1 \mathrm{~m}$ (Gambar 3 panel kanan).

Stasiun 6 merupakan stasiun di Tanjung Buyat di bagian sisi dalam Teluk Buyat. Pada stasiun ini ditemukan padang lamun campuran dengan prosentase tutupan total lamun diatas $50 \%$ yaitu berkisar antara $64 \%$ - 100\%. Dominan yang ditemukan di stasiun ini adalah lamun jenis $\mathrm{Si}$ dengan kisaran prosentase tutupan berkisar antara 30\% - 60\% (Gambar 4). Prosentase tutupan dan kondisi lingkungan di Teluk Ratatotok dapat dilihat dalam Tabel 3. Kerapatan jenis lamun setiap stasiun dapat dilihat pada Gambar 5

Gambar 5 menunjukkan kerapatan jenis lamun pada lokasi penelitian berdasarkan tunas / individu lamun perluasan area (individu $/ \mathrm{m}^{2}$ ). Pengambilan kerapatan lamun dilakukan menggunakan core yang terbuat dari flexiglass dengan luasan sebesar 0,059161 $\mathrm{m}^{2}$. Kisaran kerapatan lamun di Teluk Ratatotok antara 17 - $473 \mathrm{ind} / \mathrm{m}^{2}$. Lamun jenis Ho terlihat memiliki kerapatan paling tinggi sebesar 473 individu $/ \mathrm{m}^{2}$ pada
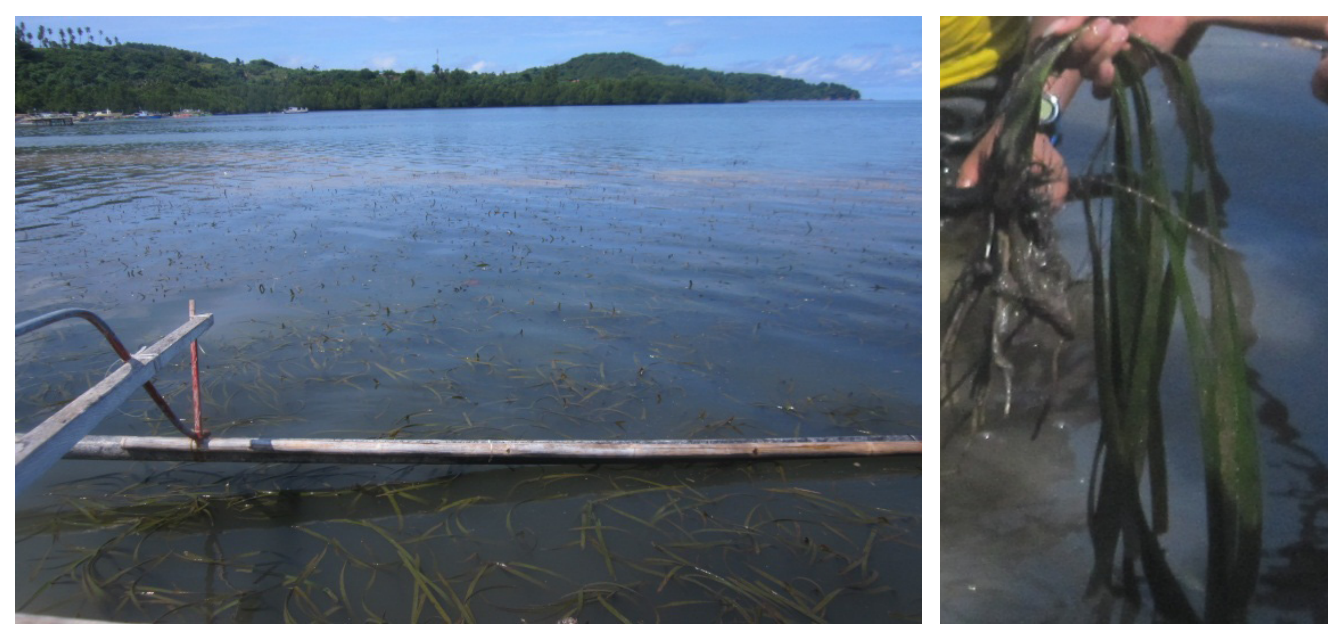

Gambar 3. $\quad$ Stasiun 2, padang lamun monospesies Ea (panel kiri), tunas Ea yang berukuran besar dengan panjang daun mencapai $1 \mathrm{~m}$ (panel kanan).

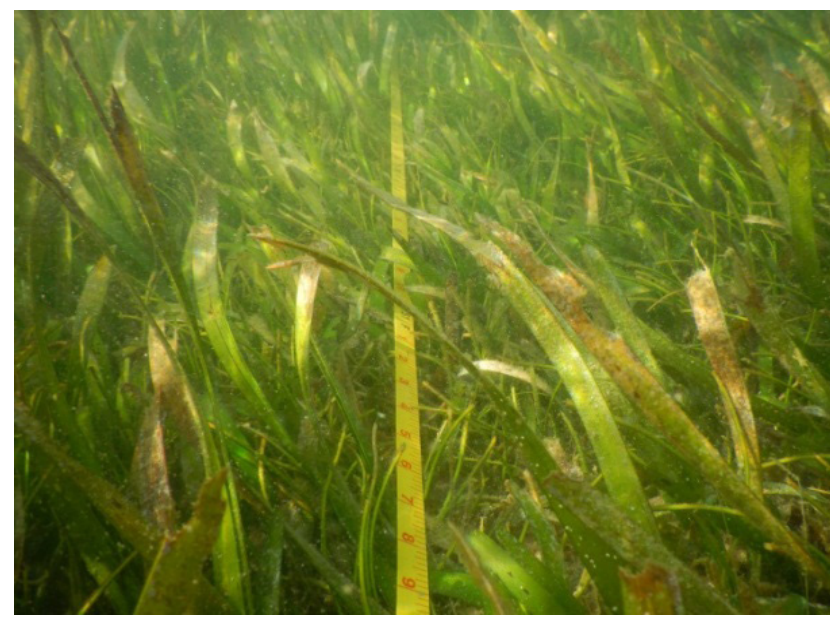

Gambar 4. Stasiun 6, padang lamun campuran (a) Syringodium isoetifolium (Si); (b) Enhalus acoroides (Ea). 
Tabel 3.

Prosentase tutupan total lamun di Teluk Ratatotok, Minahasa Tenggara, Sulawesi Utara, Juni 2013

\begin{tabular}{lllll}
\hline Stasiun & Substrat & $\begin{array}{l}\text { Kisaran } \\
\text { tutupan } \\
\text { total (\%) }\end{array}$ & $\begin{array}{l}\text { Rata-rata } \\
\text { tutupan total (\%) }\end{array}$ & Jenis lamun \\
\hline 1 & Pasir & $5-90$ & 72,67 & $\mathrm{Cr}, \mathrm{Ea}, \mathrm{Ho}, \mathrm{Si}, \mathrm{Hp}$ dan Th \\
2 & Lumpur & $60-100$ & 80 & $\mathrm{Ea}$ \\
3 & Pasir & $30-60$ & 40 & $\mathrm{Ea} \mathrm{dan} \mathrm{Cs}$ \\
4 & Pasir lumpur & $20-65$ & 40,83 & $\mathrm{Cs}, \mathrm{Ea}, \mathrm{Ho}, \mathrm{Hp}$ dan Th \\
5 & Pasir dan karang $0-60$ & 22,5 & $\mathrm{Ea}$ \\
6 & Pasir & $64-100$ & 89,5 & $\mathrm{Cr}, \mathrm{Cs}, \mathrm{Eadan} \mathrm{Si}$ \\
\hline
\end{tabular}

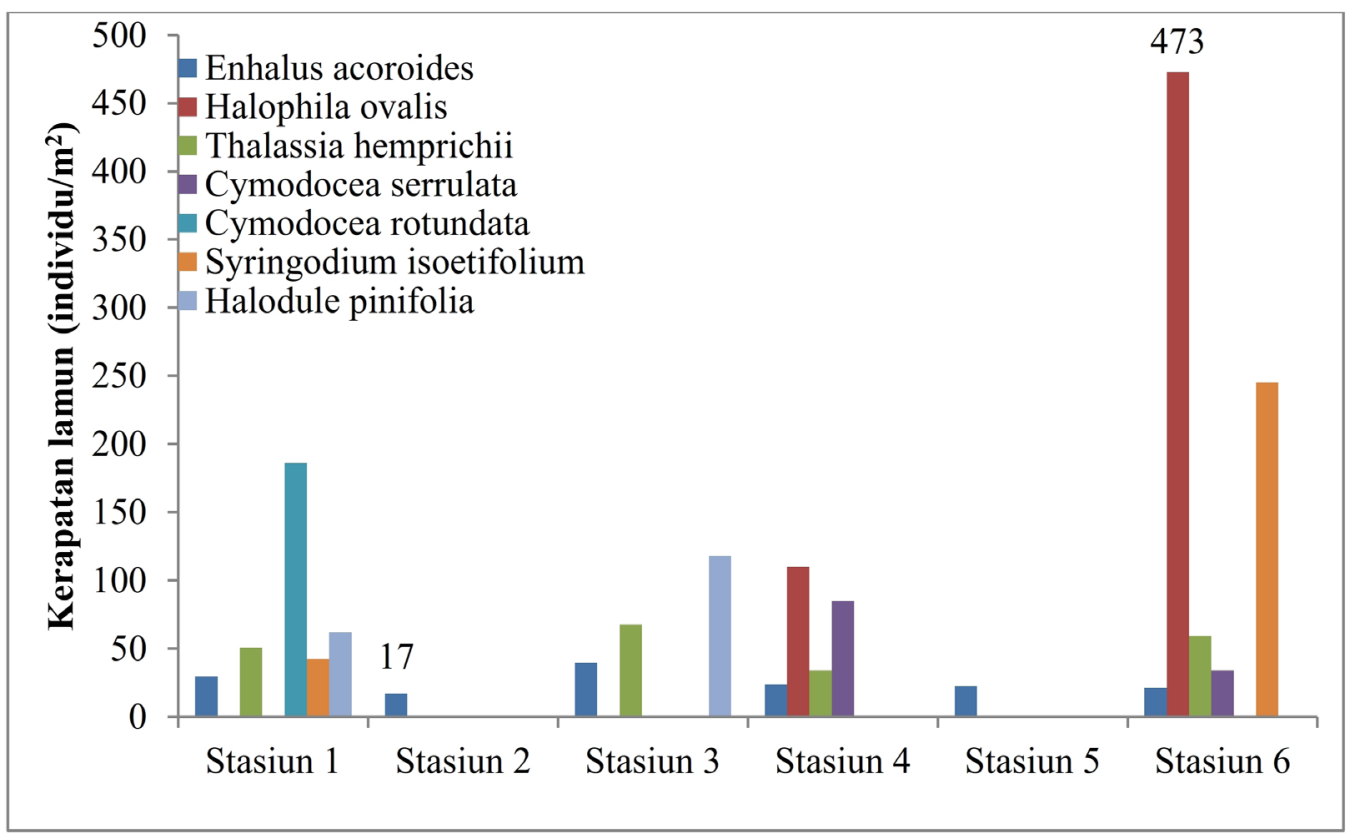

Gambar 5. Kerapatan jenis lamun di Teluk Ratatotok, Minahasa Tenggara, Sulawesi Utara, Juni 2013.

stasiun 6. Kerapatan paling rendah adalah Ea pada stasiun 2 sebesar $17 \mathrm{ind} / \mathrm{m}^{2}$. Ea terlihat ada pada semua stasiun pengamatan, hal ini memperjelas bahwa komposisi jenis lamun yang tertinggi di Teluk Ratatotok adalah jenis Ea. Terlihat juga dari enam stasiun pengamatan di Teluk Ratatotok terdapat dua stasiun lamun monospesies yaitu stasiun 2 dan stasiun 5, dimana stasiun 2 membentuk padang lamun sedangkan stasiun 5 terbentuk spot-spot kecil Ea tumbuh diantara karang dan makroalga.

Pentingnya Ea di Teluk Ratatotok diperkuat juga dengan besarnya nilai Indeks Nilai Penting jenis (INP) tertinggi pada lamun jenis Ea sebesar $128 \%$. Nilai INP untuk semua jenis lamun dapat dilihat dalam Tabel 4.

Status kondisi ekosistem/padang lamun dapat dilihat berdasarkan Kepmen LH No 200 Tahun 2004.
(Tabel 5). Berdasarkan status padang lamun di Tabel 5, maka status setiap stasiun pengamatan ekosistem lamun di Teluk Ratatotok dapat dilihat pada Tabel 6.

Dari Tabel 6, tampak bahwa status kondisi ekosistem lamun di Teluk Ratatotok dalam kondisi baik, sehat dan kaya di tiga statsiun yaitu stasiun 1,2 dan 6 . Tiga stasiun lainnya dalam kondisi rusak yaitu stasiun 3, 4 dan 5, dengan status kurang kaya/kurang sehat pada stasiun 3 dan 4 , sedangkan stasiun 5 dalam kondisi miskin. Berdasarkan hasil yang didapat ada tendensi terjadi penurunan kondisi lamun terutama lamun yang dekat dengan daratan dan terdapat pemukiman stasiun 3 dan 4 , sedangkan stasiun 5 yang berada di pulau Putus-putus, yang merupakan dominan terumbu karang lamun yang tumbuh hanya jenis Enhalus acoroides dengan spot-spot kecil terdiri dari 3-10 individu yang tumbuh di sela-sela karang. 
Tabel 4. Indeks Nilai Penting (INP) lamun di Teluk Ratatotok, Minahasa Tenggara, Sulawesi Utara bulan Juni 2013

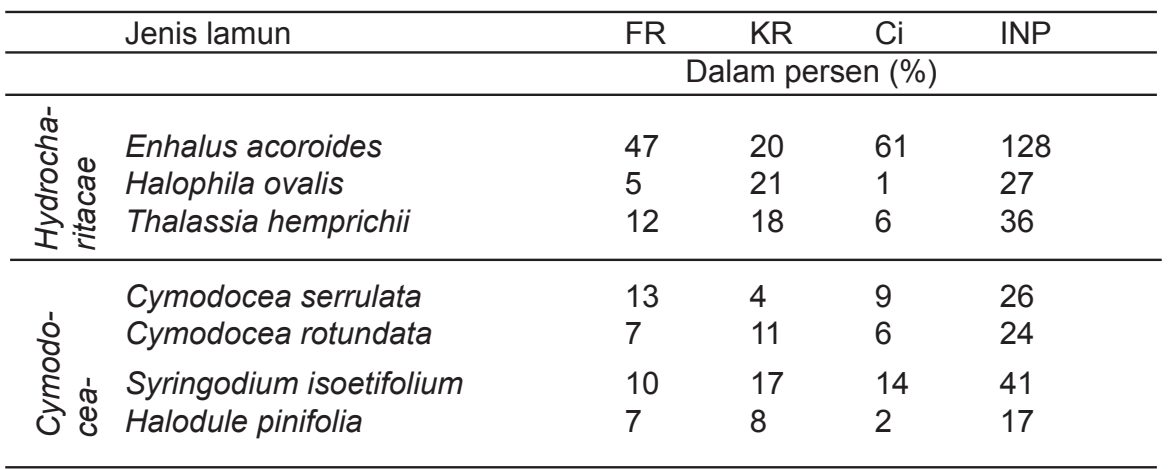

Tabel 5 .

Status padang lamun (sumber: Kepmen LH No 200 tahun 2004)

\begin{tabular}{llc}
\hline & Kondisi & \multicolumn{1}{c}{ Penutupan (\%) } \\
Baik & Kaya/Sehat & $\geq 60$ \\
Rusak & Kurang kaya / Kurang sehat & $30-59,9$ \\
& Miskin & $\leq 29,9$ \\
& & \\
\hline
\end{tabular}

Tabel 6.

Status kondisi padang lamun di Teluk Ratatotok, Minahasa Tenggara, Sulawesi Utara, bulan Juni 2013 berdasarkan Kepmen LH 200 tahun 2004

\begin{tabular}{llll}
\hline Stasiun & Penutupan (\%) & Kondisi \\
\hline 1 & 72,67 & Baik & Kaya/ sehat \\
2 & 80 & Baik & Kaya/ sehat \\
3 & 40 & Rusak & Kurang kaya/kurang sehat \\
4 & 40,83 & Rusak & Kurang kaya/kurang sehat \\
5 & 22,5 & Rusak & Miskin \\
6 & 89,5 & Baik & Kaya/ sehat \\
\hline
\end{tabular}

Diketahui lamun jenis $E$. acoroides mampu hidup pada berbagai macam substrat yaitu dari substrat pasir, karang sampai lumpur (Kiswara, 1992; Tomascik et al.,1997). Mengingat kondisi status lamun yang dalam keadaan rusak di dekat daratan dapat disebabkan karena aktivitas dari daratan seperti limbah rumah tangga, aktivitas pendaratan kapal yang tidak ramah lingkungan seperti baling-baling kapal atau perilaku pemanfaatan ekosistem lamun dalam pengambilan sumberdaya hayati seperti teripang dan kerang yang tidak ramah lingkungan.

\section{KESIMPULAN}

Lamun yang ditemukan di Teluk Ratatotok yaitu tujuh spesies lamun dalam dua famili. Famili Hydrocharitaceae ditemukan tiga jenis yaitu Enhalus acoroides (Ea), Thalassia hemprichii (Th) dan Halophila ovalis (Ho). Empat jenis dari famili Cymodoceaceae yaitu Cymodocea serrulata (Cs), Cymodocea rotundata $(\mathrm{Cr})$, Halodule pinifolia $(\mathrm{Hp})$ dan Syringodium isoetifolium (Si). Kisaran prosentase penutupan ratarata antara $22,5 \%-89,5 \%$. Kerapatan individu lamun perstasiun tertinggi lamun jenis Ho sebesar $473 \mathrm{ind} / \mathrm{m}^{2}$. Nilai INP tertinggi pada lamun jenis Ea sebesar 128\% diikuti dengan urutan ke 2 sampai ke 7 sebagai berikut: Si (41\%), Th (36\%), Ho (27\%), Cs (26\%), Cr (24\%) dan Hp (17\%).

Keberadaan lamun di lokasi penelitian berdasarkan Kepmen LH no 200 tahun 2004 sebagian dalam kondisi kurang baik atau kurang sehat. Hal ini dapat disebabkan kondisi perairan yang kurang memungkinkan lamun dapat tumbuh dengan baik dan subur. Terlihat jelas pada stasiun 5 lamun Tanjung Buyat yang mampu hidup diantara karang hidup hanya jenis Ea. Diperlukan regulasi dan aksi yang melindungi keberadaan lamun, seperti perlunya transplantasi, penanaman lamun dan peraturan yang mendukung lainnya. Salah satunya adalah pembentukan zonasi daerah perlindungan laut dengan area tertentu dapat dijadikan suatu regulasi yang baik di daerah yang memiliki tiga atau salah satu dari ekosistem utama di pesisir, yaitu ekosistem terumbu karang, mangrove dan lamun. 


\section{PERSANTUNAN}

Tulisan ini adalah bagian hasil dari kegiatan "Analisa Potensi Ekosistem Karbon Biru sebagai Mitigasi Perubahan Iklim di Wilayah Pesisir Selatan Provinsi Sulawesi Utara", TA. 2013 yang ada di Pusat Penelitian dan Pengembangan Sumberdaya Laut dan Pesisir, Balitbang Kelautan dan Perikanan, Kementerian Kelautan dan Perikanan. Penulis juga menyampaikan terima kasih kepada PT. Newmont Minahasa Raya dan Yayasan Pembangunan Berkelanjutan Sulawesi Utara atas kerjasamanya selama pelaksanaan survei.

\section{DAFTAR PUSTAKA}

Brower, J.E., J.H. Zar \& Von Ende (1990). Field and Laboratory Methods for General Ecology. Wm.C. Brown Publisher. USA. 345 pp

English, S., C. Wilkinson \& V. Baker (1994). Survey Manual for Tripocal Marine Resources. ASEANAustralia Marine Science. Project: Living Coastal Resources. Townsville.

Fachrul, F (2007). Metode Sampling Bioekologi. Bumi Aksara Press. Jakarta.

Green, E.P. \& F.T. Short. (2003). World atlas of seagrasses. University of California Press, Barkeley.

Anonim, (2013). Profil wilayah kabupaten Minahasa Tenggara. http://tataruangsulut.net/index. php/2012-12-04-12-21-12/kabupaten-minahasatenggara [270913].

Hartog, C. den \& J. Kuo. (2006). Taxonomy and biogeography of seagrasses. In: Larkum, A.W.D., R.J. Orth \& C.M. Duarte (eds.). Seagrasses: Biology, ecology and conservation. Springer, the Netherlands: 1-23.

Hemminga, M.A. \& C.M. Duarte. (2004). Seagrass ecology. Cambridge University Press: 292 hlm.

[KMNLH] [KMNLH] Keputusan Menteri Negara Lingkungan Hidup No. 200 tahun 2004. Tentang Kriteria Baku Kerusakan dan Pedoman Penentuan Status Padang Lamun

Kiswara, W. (1992). Vegetasi lamun (seagrass) di rataan terumbu Pulau Pari, Pulau Seribu, Jakarta. Oseanol di Indonesia 25:31-49. ISSN0125-9830

Kiswara, W. (2009). Perspektif Lamun dalam Produktivitas Hayati Pesisir. dalam Lokakarya
Nasional I Pengelolaan Ekosistem Lamun. Jakarta

Kuo, J. \& A.J. Mc Comb (1989). Seagrass taxonomy, structure and development. In: A.W.D. Larkum A.J. Comb \& S.A. Shepherd, (eds). Biology of seagrasses : a treatise on the biology of seagrasses with special reference to Australian region.Elsevier, Amsterdam: 6-73.

Kuo, J. \& C. den Hartog. (2006). Seagrass morphology, anatomy and ultrastructure. In: Larkum, A.W.D., R.J. Orth \& C.M. Duarte (eds.). Seagrasses: Biology, ecology and conservation. Springer, the Netherlands: 51-87.

Marba N, Holmer M, Gacia E \& Barron C. (2006). Seagrass beds and Coastal Biogeochemistry. Didalam Larkum AWD, RJ Orth; CM Duarte (eds) Seagrass: Biology and Conservation : Springer. Netherlands: 135-157.

Mc, Kenzie. Campbell, S.J \& Roder, C.A (2003). Seagrasswatch: Manual for mapping \& monitoring seagrass resources by community (citizen) volunteers 2nd edition. The state of Queensland, Department of Primary Industries, CRC Reef. Queensland. pp 104

Menteri Negara Lingkungan Hidup. (2004). Kriteria Baku Kerusakan dan Pedoman Penentuan Status Padang Lamun dalam Keputusan Menteri Negara Lingkungan Hidup No 200 Tahun 2004.

Orth, R.J., T.J.B. Carruthers, W. C. Dennison, C.M. Duarte, J.W. Fourqurean, K.L. Heck Jr., A. R. Hughes, G.A. Kendrick, W.J. Kenworthy,S. Olyarnik, F.T. Short, M. Waycott, S.L. \& Williams. (2006). A global crisis for seagrass ecosystem. Bioscience. Vol 56, No 12.

Phillips, R.c. \& E.G. Menéz (1988). Seagrasses. smithsonian contributions to the marine sciences. smithsonian institution Press, Washington d.c., 34:pp. 105.

Short, F.T., R.G. Coles \& C. Pergent-Martini. (2001). Global seagrass distribution. In: Short, F.T. \& R.G. Coles (eds.). Global seagrass research methods. Elsevier Science, Amsterdam: 5-30.

Tomascik, T., Nontji, A. \& Moosa MK. (1997). The Ecology of Indonesian Seas part Two. Periplus edition. 
